\title{
The Impact of Self-Management Techniques to Improve University Students' Social Cognition
}

\author{
Mita Sri Handayani ${ }^{1 *}$, (D Muhammad Nur Wangid ${ }^{1}$, Andre Julius $^{2}$ \\ Universitas Negeri Yogyakarta, Indonesia ${ }^{1}$ \\ Universitas Ma'soem, Indonesia ${ }^{2}$ \\ هitasrihandayani.2017@student.uny.ac.id*
}

\begin{abstract}
The background of the current study is the urgency of possessing good social cognition to adapt to the social changes that are happening quickly. Weak social cognition makes individuals less in empathy, aggressive or unhappy in their daily life. The link between self-management and social cognition lies in cognitive adjustment. Hence, the authors think it is important to do research that focuses on the implementation of counseling with self-management techniques in developing social cognition. The authors aimed to investigate the effectiveness of selfmanagement in improving social cognition. The present study used one group pretest-posttest quasi-experiment. We invited 10 students from Universitas Ma'soem, Indonesia to participate in the experiment. They were selected based on a low social cognition score after filling the selfreport of nineteen items social cognition scale. The results showed counseling with self-management techniques effective in improving university students' social cognition. Besides, limitations and recommendations are discussed.
\end{abstract}

\section{INTRODUCTION}

Social media has a huge influence on today's life. Individual lives can be judged fun or vice versa based on social media uploads. For people, especially teenagers, social media is their reference and standard of living. Some teenagers become hyperactive on social media by frequently posting their daily activities that will describe their lifestyles that try to keep up with the times. Within the scope of social media, individuals who get attention, and cultivate imagery can be categorized by self-existence (Nasrullah, 2016; Rakanda, 2020)

Such social life changes if not followed wisely will cause various problems such as cyberbullying, child safety threats, even stress, and frustration. World Health Organization (2019) explained that the new phenomenon affecting adolescent mental health today is due to technological developments and social media. Kelly et al. (2018) surveyed excessive social media use causing symptoms of depression $50 \%$, online harassment $61.3 \%$, low self-esteem $30.7 \%$, weight dissatisfaction $70 \%$, unhappy with appearance $27.2 \%$, and lack of sleep hours $52.7 \%$.

Social cognition needs to be owned by the current generation to adapt to the social changes that are happening. Individuals should be able to understand the surrounding environment including the social environment in cyberspace. Individuals need to realize that each other is a unique individual, whether it concerns his nature, interests, values, or feelings (Mudjiran, 2007; Ranny et al., 2017). Emotional maturity is an important aspect in the development of social cognition.

How to cite:

E-ISSN:

Published by:
Handayani, M., Wangid, M., \& Julius, A. (2021). The Impact of Self-Management Techniques to Improve University Students' Social Cognition. Islamic Guidance and Counseling Journal, 4(1). https://doi.org/10.25217/igcj.v4i1.1247

2614-1566

Institut Agama Islam Ma'arif NU (IAIMNU) Metro Lampung 
The ability to empathize and sympathize with others is an indicator of social cognition maturity. From a Positive youth development perspective, Caring is an expression of sympathy and empathy for others (Lerner et al., 2009; Suryahadikusumah \& Yustiana, 2016). This aspect emphasizes on teenagers to be sensitive and care about the social situation they face. Being sensitive means being able to understand the background of a social change, and understand how to put yourself right in the situation.

The challenges faced with the social life of this generation are the tendency of conformity attitudes, namely the tendency to give up or follow opinions, opinions, values, habits, passions, or desires of others (peers). Kilford et al. (2016) found that the success of adolescents facing the transition to adulthood requires rapid refinement and integration of cognitive processes. The process affects many typical adolescent behaviors, such as peer influence and sensitivity to social exclusion, and others.

The correlation between self-management and social cognition lies in cognitive adjustment. A new study shows social cognition plays a role as a resource that can control one's decision-making through perception. Perception, understanding, and interpretation of other people's emotions are fundamental aspects of social interaction and the need for integration of various perception skills, social cognition, and affective (Hidayati, 2018). This is a basic aspect of affective perception, such as perception and emotional recognition, and more complex social cognitive processes, such as the ability to understand the affective state of others, sometimes referred to as affection mentality.

Self-management techniques focus on affective maturity and individual cognition. Yates argues that in such techniques individuals are directed to managing by antecedent and managing by consequence or also referred to as a form of behavioral intervention techniques, which are the implementation of cognitive or affective techniques (Hidayati, 2018; Mudarya \& Setiawan, 2016; Setiawan \& Dharsana, 2018). Affective techniques in self-management is a program that aims to change one's emotions and attitude towards the situation faced. While cognitive techniques are useful in changing the mind and its patterns. Also, self-management can help teens to manage

\section{Rationale of the Current Study}

Based on the findings of previous research, it is estimated that self-management is an important factor in encouraging adolescent social cognition. Self-regulation skills, planning skills, emotional management skills, or definitions of expectation become personal resources developed in self-management techniques. The research aims to prove the significant influence of self-management techniques on social cognition. Previous research has only proven the link between self-management variables and social cognition. In this study, researchers implement self-management as a counseling technique in developing student social cognition.

\section{Hypotheses}

1. Self mangament techniques are effective in developing student social cognition.

2. Self-management techniques are not significantly effective if there is no difference between social cognition before and after being given the self-management technique.

\section{METHODS}

\section{Research Design}

Quasi-experiment with one group pretest-posttest design was used. The research process focused on one group of experiments by noticing changes in social cognition before and after the self-management counseling process. In the early stages, researchers pre-tested participants to obtain their social cognition profiles, then identified aspects of cognition that 
were still weak. The use of self-management techniques is focused on these aspects. In the final stage or reflection of the results of self-management application, researchers conducted post tests on participants.

\section{Participants}

A total of 10 partisipants $($ Male $=3$, Female $=7$; Age $M=18.7$ ) were selected purposively from 30 students of ma'soem University counseling guidance study program. Based on the results of pre-test measurements the sample had the lowest score and factually lacked in socializing, difficulty understanding the social situation around it, and easily felt anxious when it came to showing itself in an off-campus environment.

\section{Instruments}

The research instrument was adapted from a student social cognition questionnaire developed by Nejati et al. (2018). The social cognition measuring instrument uses a Likert scale that refers to four social cognition domains. The four social cognition domains developed are mapped in Table 1 . The instrument has 19 valid items, with a validity value of .76 and a reliability value of $\alpha=.8$.

Table 1. Domain of social cognition

\begin{tabular}{ll}
\hline Domain & Description \\
\hline Emotional Percerption & The way individuals perceive and use emotional information includes both \\
& simple and complex processes. Related to non-verbal communication \\
Theory of Mind & The capacity to understand the mental state of others. The measured abilities \\
include assessing beliefs, interpreting cues, and the ability to understand \\
metaphors. \\
Interpret social cues, understand the social environment, and understand \\
situations contextually \\
The way individuals interpret, explain, or understand the situation positively, \\
Attributional Style & and relate it to the individual's internal and external factors \\
\hline
\end{tabular}

\section{Procedures}

The framework of self-management technique counseling using three core stages 1) Self-monitoring, 2) Self Evaluation, and 3) Reinforcement. An overview of the framework is presented in Figure 1.

Figure 1. The Framework of Self -Management
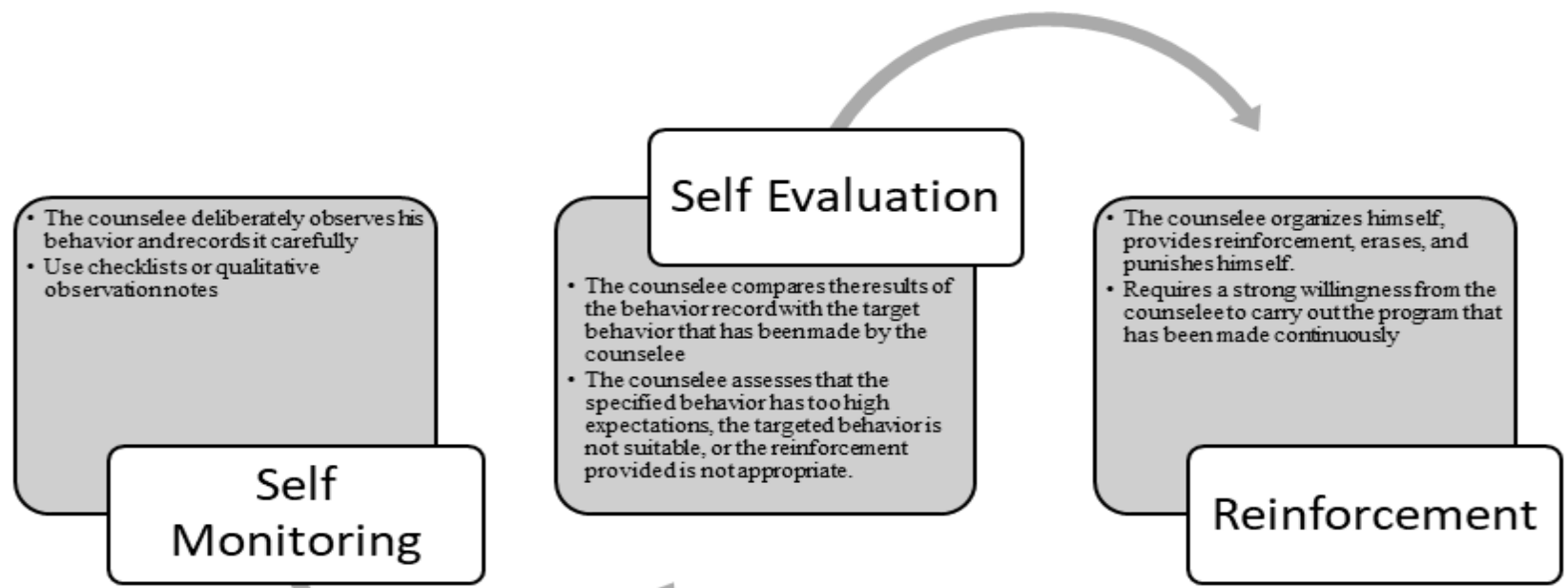


\section{Data Analysis}

The study used two forms of data analysis, are t-test and $\mathrm{N}$-gain test. T-test used to determine the significant effect of the intevention, while the $\mathrm{N}$-gain test used to analyze the magnitude of the effect of self-management on social cognition.

\section{RESULTS AND DISCUSSION}

\section{Results}

Table 2 showed the demographic information of the participants. The demographic informations are the frequency of gender and age of the participants.

Table 2. Participants demographics $(\mathrm{N}=10)$

\begin{tabular}{lll}
\hline Variables & $\mathrm{F}$ & $\%$ \\
\hline Gender & & \\
Male & 3 & 30 \\
Women & 7 & 70 \\
Age & & \\
18 & 4 & 40 \\
19 & 5 & 50 \\
20 & 1 & 10 \\
\hline
\end{tabular}

In Table 3, the social cognition score obtained by the sample was obtained both before the counseling session and after counseling using self-management. There was a change in score that did not go far between before and after the counseling session.

Table 3. Data Description and t-test $(\mathrm{N}=10)$

\begin{tabular}{lllllll}
\hline Intervention Group & Min & Max & M & SD & t & p \\
\hline Pretest & 51 & 57 & 54.20 & 2.20 & \multirow{2}{*}{5.23} & $<.05$ \\
Postest & 56 & 69 & 62.50 & 4.27 & & \\
\hline
\end{tabular}

Based on the data in Table 3, the minimum value obtained by the sample during pre-test $=51$, maximum score $=57$, average $=54.2$, and Std. Deviation $=2.20$. In the post-test the minimum value obtained $=56$, the maximum score is 57 , the average $=62.5$, and Std. Deviation $=4.26$. Variance post-test scores are more diverse than pre-tests. Significance differences in social cognition in pre-test and post-test analyzed using t-test. The test results are also presented in Table 3 as obtained $t=5.2$ and $\mathrm{p}<.05$. The results show that hypothesis 1 is accepted, in the other had hypoothesis 2 is rejected. It means that counseling with selfmanagement techniques are effective in improving university students social cognition.

\section{Discussion}

The results of the study are in line with the research of Safithry \& Anita (2019) group counseling with self-management techniques can lower the level of social prejudice, the indicator achieved is the subject will not be too quick to judge others because not necessarily what others are doing is wrong and what we are doing is right. Utami (2017) argues that selfmanagement is an effective method to monitor individual conditions and adapt to maintain or improve the quality of life for the better, based on the results of descriptive analysis seen an increase in the average value of psychological well-being participants after being given selfmanagement ability training.

Group counseling sessions using self-management are focused on controlling the subject's thinking towards their social environment. The subject reassesses his perception of his position in the environment, the environmental responses to his habits, and assesses the emotional responses that arise from him. Changes that are indicators of achievement are 
subjects more flexible with personal values, try to understand the situation carefully, and learn to express emotions reasonably. Thus self-management has an impact on the ability to regulate emotions.

The ability to manage emotions is very important because when a child or adolescence can regulate his emotions therefore he will be more productive than children who lack emotional skills.People who are emotionally intelligent or able to manage their emotions have been described as people who are able to adjust well, warmly, sincerely, persistently and optimistically. This is believed to include social and cognitive functions as related to emotional expression (Awaliyah et al., 2019).

Cognitively, the incapableness of managing social perception has an impact on impulsive behavior. Impulsive individuals are characterized by the absence of reflexive control and anticipation of posterior consequences, which leads to the making of errors in certain situations (Dalley et al., 2011; Smith et al., 2016). Emotionally, impulsivity is characterized by a low tolerance to frustration, always feeling dependency, and little control resources to regulate impulses to respond quickly and precisely (Bridgett et al., 2015; Guinote, 2017).

Social impulsivity has been associated with socialization difficulties (Van Stekelenburg \& Klandermans, 2017), low empathy (Baldner et al., 2015), prosociality (Do et al., 2017), dependent relationships (Odac1 \& Çelik, 2016), aggressiveness (Johnson \& Carver, 2016), and manipulation (Salekin, 2016). Social cognitive developed through self-management is an effort to improve the ability to understand social situations and stimulate subjects to try to socialize in new ways.

The use of self-management in the development of social cognitive proved effective in reducing aggressiveness. Retnowulan \& Warsito's research (2013) described the frequency of juvenile delinquency among groups of students assisted by self-management strategies decreased significantly compared to the group of students who were helped by conventional methods. Nisa's findings (2013) proved that self-management strategies can reduce aggression behavior, from the results of the study it is known that subjects who have high aggression behavior can decrease their aggression behavior, they can monitor themselves, monitor aggression behavior and things that cause aggressive behavior and then control the stimuli of aggressive behavior and then give boosters to themselves not to repeat their aggression behavior.

In the context of Islamic counseling, self-management is identical to the practice of Tazkiyatun Nafs. Tazkiyatun Nafs in counseling is a process of self-recognition (assertive) of weaknesses and self-errors that have been an obstacle to a personal change of a person, thereby undermining the defense mechanism itself, self-introspection in every process, and self-commitment to change and consistent with the reality that must be faced with a new way of his behavior (Alfaiz et al., 2019). Self-management is done by stimulating the individual to understand the wrong thoughts about good and wrong, see himself in-depth, and help the individual form his or her commitment or regulation.

Self-Management Engineering Group Counseling Tazkiyatun Nafsi has a vertical dimension (theistic) that uses the values of tazkiyatun nafsi as a reference in changing thoughts, feelings, and behaviors through exercises and habituation packed by way of M.A.B.I.T (Agustin, 2018). Operationally Agustin et al. (2017) outlines the form of selfmanagement in the context of Islamic counseling, among others 1) individuals must be aware of the intention, namely the individual mobilizer to do something, in psychology known as "intention"; 2) habituation of prayer, can give rise to discipline attitudes and can train to be able to focus; and 3) train discipline and train yourself to have the ability to control themselves through fasting. 


\section{Limitations and Sugestions}

Research has limitations in both practice sessions and research methods. In counseling sessions using self-management still need supporting interventions to strengthen behavior changes, such as simulating behavior changes or assertive exercises. Further research methods can use single subjects to make behavior changes more clearly described.

\section{Implications}

Research has implications for developing social cognition through self-management. Self-management can stimulate a wiser perspective on social situations that can be faced by students. However, it still needs to be supported by exercise and assignments in the counseling process. Students can be given additional assignments in the form of journaling, assertive training, effective living practices, etcetera.

\section{CONCLUSIONS}

Self-management counseling techniques are effective in improving social cognition. Social cognitive developed through self-management is an effort to improve the ability to understand social situations and stimulate subjects to try to socialize in new ways. In counseling sessions using self-management still need supporting interventions to strengthen behavior changes, such as simulating behavior changes or assertive exercises. Further research methods can use single subjects to make behavior changes more clearly described.

\section{ACKNOWLEDGMENTS}

Sincere thanks to all participants who were willing to follow the counseling process in the study. Best regards to Ma'soem University which permitted and allowed authors invited their students to participate in the current study.

\section{AUTHOR CONTRIBUTIONS STATEMENT}

As the first author, MSH designed research implementation, data collection, and field interventions. MNW provides direction and helps build theoretical frameworks, validates instruments and designs implementation. AJ provided direction and field supervision during the implementation of interventions and data analysis.

\section{REFERENCES}

Agustin, L., AW, S. A. S., \& Rahayu, M. S. (2017). Konseling Kelompok Berbasis Teknik Self-Management Tazkiyatun Nafsi: Suatu Intervensi Psikologi Dalam Peningkatan Self-Direction In Learning Siswa. Jurnal Psikologi UIN Sultan Syarif Kasim, 13(1), 112. https://doi.org/http://dx.doi.org/10.24014/jp.v13i1.2399

Agustin, L. (2018). Intervensi psikologi Islam: Model konseling kelompok dengan teknik self-management-tazkiyatun nafs. Jurnal Psikologi Islam, 5(2), 75-86. Google Scholar

Alfaiz, A., Yandri, H., Kadafi, A., Mulyani, R. R., Nofrita, N., \& Juliawati, D. (2019). Pendekatan Tazkiyatun An-Nafs untuk membantu mengurangi emosi negatif klien. Counsellia: Jurnal Bimbingan Dan Konseling, 9(1), 65-78. http://doi.org/10.25273/counsellia.v9i1.4300

Awaliyah, I. T. A., Taufiq, A., \& Hafina, A. (2019). The Effectiveness of Sociodrama to Improve Students' Anger Management Skills. Islamic Guidance and Counseling Journal, 2(2), 56-65. https://doi.org/10.25217/igcj.v2i2.397

Baldner, C., Longo, G. S., \& Scott, M. D. (2015). The relative roles of drive and empathy in self-and other-focused financial decision making. Pers. Indiv. Differ, 82, 7-13. https://doi.org/10.1016/j.paid.2015.01.025 
Bridgett, D. J., Burt, N. M., Edwards, E. S., \& Deater-Deckard, K. (2015). Intergenerational transmission of self-regulation: a multidisciplinary review and integrative conceptual framework. Psychol. Bull., 141, 602-654. https://doi.org/10.1037/a0038662

Dalley, J. W., Everitt, B. J., \& Robbins, T. W. (2011). Impulsivity, Compulsivity, and TopDown Cognitive Control. Neuron, 69(4), 680-694. https://doi.org/10.1016/j.neuron.2011.01.020

Do, K. T., Guassi Moreira, J. F., \& Telzer, E. H. (2017). But is helping you worth the risk? Defining Prosocial Risk Taking in adolescence. Developmental Cognitive Neuroscience, 25, 260-271. https://doi.org/10.1016/j.dcn.2016.11.008

Guinote, A. (2017). How power affects people: activating, wanting, and goal seeking. Аnnu. Rev. Psychol, 68, 353-381. https://doi.org/10.1146/annurev-psych-010416-044153

Hidayati, B. M. R. (2018). Efektifitas Pelatihan Self-management sebagai Upaya Meningkatkan Self Regulated Learning Siswa Kelas VII MTs Sunan Ampel Pare. Journal An-Nafs: Kajian Penelitian Psikologi, 3(1), 20-45. https://doi.org/10.33367/psi.v3i1.501

Johnson, S. L., \& Carver, C. S. (2016). Emotion-relevant impulsivity predicts sustained anger and aggression after remission in bipolar I disorder. Journal of Affective Disorders, 189, 169-175. https://doi.org/10.1016/j.jad.2015.07.050

Kelly, Y., Zilanawala, A., Booker, C., \& Sacker, A. (2018). Social Media Use and Adolescent Mental Health: Findings From the UK Millennium Cohort Study. EClinicalMedicine, 6, 59-68. https://doi.org/10.1016/j.eclinm.2018.12.005

Kilford, E. J., Garrett, E., \& Blakemore, S. J. (2016). The development of social cognition in adolescence: An integrated perspective. Neuroscience \& Biobehavioral Reviews, 70, 106-120. https://doi.org/10.1016/j.neubiorev.2016.08.016

Lerner, J. V., Phelps, E., Forman, Y. E., \& Bowers, E. P. (2009). Positive Youth Development. In Handbook of Adolescent Psychology. John Wiley \& Sons, Inc. https://doi.org/10.1002/9780470479193.adlpsy001016

Mudarya, I. N., \& Setiawan, G. D. (2016). Efektifitas Model Konseling Behavioral Dengan Strategi Self-Management Model Yates Dengan Model Cormier Terhadap Pengembangan Self Outonomy Ditinjau Dari Pola Asuh Orang Tua. Daiwi Widya, 3(1). Google Scholar

Mudjiran, D. (2007). Perkembangan Peserta Didik. UNP Press. Google Scholar

Nasrullah, R. (2016). Teori dan riset media siber (cybermedia). Prenadamedia Group. Google Scholar

Nejati, V., Kamari, S., \& Jafari, S. (2018). Construction and Examine the Psychometric Characteristics of Student Social Cognition Questionnaire (SHAD). Social Cognition, 7(2), 123-144. https://dx.doi.org/10.30473/sc.2018.29262.1931

Odacı, H., \& Çelik, Ç. (2016). Does internet dependence affect young people's psycho-social status? intrafamilial and social relations, impulse control, coping ability and body image. Comput. Hum. Behav, 57, 343-347. https://doi.org/10.1016/j.chb.2015.12.057

Rahma Hidayati, B. M. (2018). Efektifitas Pelatihan Self-management sebagai Upaya Meningkatkan Self Regulated Learning Siswa Kelas VII MTs Sunan Ampel Pare. Journal An-Nafs: Kajian Penelitian Psikologi, 3(1), 20-45. https://doi.org/10.33367/psi.v3i1.501

Rakanda, D. R. (2020). Penggunaan Media Sosial Instagram Dalam Pembentukan Identitas Diri Generasi Z Atau Igeneration Di Desa Cawas [Universitas Pembangunan Nasional Veteran Yogyakarta]. Google Scholar

Ranny, R., AM, R. A., Rianti, E., Amelia, S. H., Nova, M., Novita, N., \& Lestarina, E. (2017). Konsep Diri Remaja dan Peranan Konseling. Jurnal Penelitian Guru Indonesia, 2(2), 40-47. https://doi.org/10.29210/02233jpgi0005 
Retnowulan, D. A., \& Warsito, H. (2013). Penerapan strategi pengelolaan diri (selfmanagement) untuk mengurangi kenakalan remaja korban broken home. Jurnal BK Unesa., 03(01), 335-340. Google Scholar

Safithry, E. A., \& Anita, N. (2019). Konseling Kelompok Dengan Teknik Self-management Untuk Menurunkan Prasangka Sosial Peserta Didik. Suluh: Jurnal Bimbingan Dan Konseling, 4(2), 33-41. https://doi.org/10.33084/suluh.v4i2.624

Salekin, R. T. (2016). Psychopathy in childhood: why should we care about grandiosemanipulative and daring-impulsive traits? Brit. J. Psychiat., 209, 189-191. https://doi.org/10.1192/bjp.bp.115.179051

Nisa, F. S. (2013). Penerapan strategi self management untuk mengurangi perilaku prokrastinasi akademik pada siswa kelas VIII E SMP Negeri 1 Sukomoro Nganjuk Tahun Ajaran 2012-2013. Jurnal BK UNESA, 2(1). Google Scholar

Setiawan, G. D., \& Dharsana, I. K. (2018). Strategi Self-management Model Yates dan Model Cormier Terhadap Pengembangan Self Outonomy ditinjau dari Pola Asuh. Bisma The Journal of Counseling, 2(1), 48-57. http://dx.doi.org/10.23887/bisma.v2i1.19974

Smith, C. T., Wallace, D. L., Dang, L. C., Aarts, E., Jagust, W. J., D’Esposito, M., \& Boettiger, C. A. (2016). Modulation of impulsivity and reward sensitivity in intertemporal choice by striatal and midbrain dopamine synthesis in healthy adults. Journal of Neurophysiology, 115(3), 1146-1156. https://doi.org/10.1152/jn.00261.2015

Suryahadikusumah, A. R., \& Yustiana, Y. R. (2016). Bimbingan Dan Konseling Komunitas Untuk Mendukung Positive Youth Development (Penelitian Tindakan Partisipatoris Bersama Komunitas Schoolzone). Jurnal Penelitian Pendidikan, 16(2), 137-146. https://doi.org/10.17509/jpp.v16i2.4235

Utami, N. M. S. N. (2017). Pengaruh Self-management Ability Terhadap Psychological WellBeing Penderita DM Tipe 2. CALYPTRA, 6(2), 1590-1602. Google Scholar

Van Stekelenburg, J., \& Klandermans, B. (2017). Individuals in movements: a social psychology of contention. In Handbook of Social Movements Across Disciplines, eds C.

M. Roggeb and B. Klandermans (pp. 103-139). Springer. https://doi.org/10.1007/9783-319-57648-0_5

World Health Organization. (2019). Adolescent development. Google Scholar

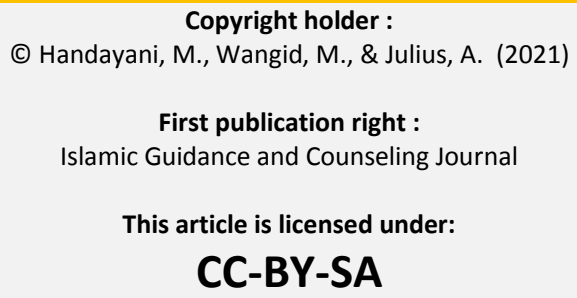

